\title{
Youth Empowerment and the Integration of Entrepreneurship Education into Technical Vocational Education and Training (TVET) in Nigeria
}

\author{
Vincent E.Onweh (Ph.D) \\ Nsini Akpan (Ph.D) \\ Caleb, E. Emmanuel
}

Doi:10.5901/ajis.2013.v2n2p211

\author{
Department of Vocational EducationFaculty of Education, \\ University of Uyo, Uyo Akwa Ibom State, Nigeria \\ emmezik@yahoo.com 234-8100603902
}

\begin{abstract}
All economies of the world possess four essential elements, viz, land; labour; capital and entrepreneurship, though they are not evenly distributed. Entrepreneurship education seeks to provide students with knowledge, skills and motivation to encourage entrepreneurial success. The highest pool of potential workforce for any nation is its university students. This study was carried out in the University of Uyo, Nigeria, to investigate the appropriate strategies for integrating entrepreneurship education into TVET. 2 specific purposes and 2 research questions guided the study. A 30 item instrument tagged Entrepreneurship Training and Integration Questionnaire was used in collecting data for the study. 74 TVET lecturers constituted the population and a total of 48 were randomly selected to form the sample. It was found that industry-academia interaction, appropriate instructional methods and the development of problem solving skills, creativity, risk taking ability and team working skills were vital for developing entrepreneurship among students. It was recommended that there should be industry-academia interactions and that students should be guided to discover knowledge by themselves.
\end{abstract}

Key words: Entrepreneurship, TVET, Integration, Youths, Entrepreneurship education.

\section{Introduction}

All economies of the world possess four essential elements, namely, land; labour; capital and entrepreneurship. Land represents the natural resources available. This entails soil, rivers and trees. The entire material universe exclusive of people and their products, everything physical (other than human beings) which is not the result of human effort is within the economic definition of land. This concept includes not only the dry surface of the earth, but all natural materials, forces and opportunities. The trees in a virgin forest are all termed as land, in a cultivated forest, they are all wealth. To understand the meaning of land as a factor of production, it must be conceived and defined broadly as the entire set of natural opportunities. Labour is viewed as all human exertion in the production of wealth and services. Mental toil is labour as well as muscular effort. All who participate in production by their mental and physical efforts are labourers in the economic sense. Labour stands for all human inputs in the form of skills and expertise in the manufacture of a product or offering of services. The work of technologist and crafts men, fall in this domain.

Capital is wealth used in the process of production. Any item of wealth could be used as capital. It could be sold or used in production. Capital includes all resources made available for the enterprise. They include buildings, equipment, tools, materials and finance needed for the smooth running of business. Wealth is all materials produced by labour for the satisfaction of human desires and having exchange value. Wealth is material. Entrepreneurship goes beyond just starting a venture, entrepreneurship is a process through which individuals identify the opportunities in their environment, respond to these opportunities by identifying, selecting and allocating the resources needed to exploit that opportunity and create value. This creation of value is possible through the identification of unmet needs and opportunities for change and improvement. An entrepreneur is one who organises, manages and assumes the risks of a business. Entrepreneurship on the other hand, represents the ideas, innovation, talent, risks and organisational skills required to assemble all the factors of production in a bid to make profits. 
A common trait of all entrepreneurs is their risk taking abilities. Entrepreneurs are risk takers, who see problems as opportunities and entrepreneurial success being dependent on identifying the opportunities in the market place and initiating change to create values for all. They manage and assume the risks of the enterprise. They improve on established products and services and also create new ones. Entrepreneurs draw up the initial plan, some design the machine, develop the process and organise the workers. Entrepreneurship thrives in an open market. In a free market economy, one strong incentive for entrepreneurship is to please customers and make profit. In order to flourish, an enabling environment needs to be created and free markets encouraged.

Entrepreneurship education seeks to provide students with knowledge, skills and motivation to encourage entrepreneurial success. Entrepreneurship entails testing ones ideas against an external reality. It is about transforming ideas into realities. By focussing on youth entrepreneurship education, government can foster future innovations. When young people start developing technologies that are combined with available resources in their communities, employ and train the locals, develop products and sell for both local and international consumption, then, Technical and Vocational Education and Training (TVET) would have succeeded in Nigeria. This is only possible if Entrepreneurship education is integrated into the TVET curriculum especially in the universities.

Entrepreneurship education would be important for a number of reasons including:

1. Universities serving as facilitators of an entrepreneurial culture - a strong focus on entrepreneurship will undoubtedly spill over to non-business students and help foster an entrepreneurial culture.

2. Universities acting as mediator of skills - entrepreneurship students pursuing an entrepreneurial career would be equipped with a set of skills that will help them identify viable business ideas and provide them with practical approach to entrepreneurship. Entrepreneurial courses may complement general education for a broad range of students or serve as a specialist course for entrepreneurship students.

3. Universities working as locomotives of regional business development - a strong political focus on entrepreneurship will likely boost university relations with other stakeholders in the entrepreneurial field and facilitate the creation of regional policies and favourable entrepreneurship infrastructures. (National Agency For Enterprise and Construction, 2004) .

Entrepreneurship education offers solutions to global economic crisis as students learn leadership and management skills, as well as interpersonal skills, which are transferable skills and prerequisites for success in the present global economic age. It seeks to prepare people, particularly youths, to be responsible, young and enterprising individuals, who become entrepreneurs or entrepreneurial thinkers, by bringing into the classroom knowledge of the opportunities to take risks, manage the results and learn from the outcomes, contrary to normal academic work, were they only gather knowledge that may not be applicable to best practices in the wider world.

Entrepreneurial education can be oriented towards either the opening of a new organisation; that is, by promoting innovation or introducing new products or services in existing firms. This approach is called corporate entrepreneurship or "intrapreneurship". Both concepts are in line with the objectives of the national policy on education $(F G N, 2004)$ which states that Technical College graduates upon graduation are supposed to have three options, viz: secure employment in the industries, pursue further education in advance craft in a higher technical institutions or set up their own business and become self-employed.

Entrepreneurship education further provides opportunities for work based experiences. Students who participated in Technical Education programmes with work experiences, are more likely to be employed than students who did not participate in such activities. It also provides opportunities for developing leadership, management and interpersonal skills. Students can launch their own initiatives, nurture them to fruition by interactions and communications amongst other players and participants. This interaction process can lead to the development of problem solving skills as well as analytical and creative abilities, which are essential to success in the business world. The students will have opportunities to develop financial planning and prudence, discipline and goal oriented attitudes.

The range of production for which the entrepreneur sticks his head, initiative and resources, should go beyond factory production to include the provision of personal services, such as supply of security, laundry services, home and office maintenance, car servicing and maintenance, marketing of industrial products as sole agents, consulting, recycling of products and the setting up of one's own workshop or business centre, especially with respect to an acquired vocational skills and knowledge. Therefore, entrepreneurial education, whatever its content and process, should be able to orient young Nigerians into self-reliant organisation of production. 
Nigeria has a growing youth population with an educational system that turns out millions of graduates every year. A rule of thumb is that youth unemployment rates tend to be approximately twice the adult rate and it is rising sharply across much of the developed and developing world alike. In countries with the most severe youth unemployment rates, a quarter of young people can be looking for work. Unemployment in Nigeria stands at 23\%. It is widely accepted that this is not merely a short-run waste of human resources and a source of unhappiness among young people, it may have longterm scarring effects on the working adults and far reaching implications for the next generation (Blanchflower \& Andrew, 2007). The persistence of unemployment problem seems to demonstrate that standard economic policies have been insufficient. Western governments are searching for new alternatives. One is the idea that policy should attempt to create more entrepreneurship among the young. It is not obvious that even a large new supply of young entrepreneurs would solve the imminent jobs crisis. Nevertheless, there are a number of potential benefits often discussed by pundits. These include:

1. Entrepreneurship may promote innovation and thus create new jobs.

2. There may be a direct effect on employment if new young entrepreneurs hire fellow youths from the dole queues.

3. New small firms may raise the degree of competition in the product market, bringing gains to consumers.

4. Young entrepreneurs may be particularly responsive to new economic opportunities and trends.

5. Greater self-employment among young people may go along with increased self reliance and well-being.

Economists have little evidence, however, on whether these hypothetical benefits exist in practice. The beginning of the twenty-first century may mark a particularly appropriate time for young entrepreneurs. Some commentators argue that new opportunities abound due to technological change, the fragmentation of markets and increased deregulation across Europe for example (Blanchflower \& Andrew, 2007).

\section{Statement of the Problem}

The era when possession of a certificate was a guarantee for employment has gone. The present era calls for education that equips one with the necessary vocational skills and knowledge for self employment. The ability of self reliant organisation of production comes from the integration of entrepreneurship education into TVET. About two decades ago, the National Directorate of Employment introduced some entrepreneurship programmes, but the programmes seem not to be effective enough in addressing the growing graduate unemployment in Nigeria, because it has not been built into the vocational curriculum, but offered on an ad hoc administration. Furthermore, while the thrust might be on the government to ensure an enabling environment to foster innovativeness and entrepreneurship, there is not within the Nigerian population, a substantial proportion with entrepreneurial motivations and inclinations. The problem of this study, put in a question form is how would an enabling environment that would foster innovativeness and entrepreneurship education be provided for the youths?

\section{Purpose of the Study}

The central purpose of this study is to ascertain ways of creating an enabling environment that would foster innovativeness and entrepreneurship education for the youths. Specifically, the study intended to:

1. Determine appropriate methods of integrating entrepreneurship into TVET.

2. Determine factors of entrepreneurial activities needed for participation in the global knowledge economy.

\section{Research Questions}

Two research questions guided this study.

1. What are the appropriate methods of integrating entrepreneurship education into TVET in Nigeria?

2. What are the factors of entrepreneurial activities needed by TVET students in Nigeria?

\section{Research Methods}

A survey design was adopted for the study. The design was considered suitable for the study as it employs the study of a small sample to make inference on a larger population. This study was a descriptive research. Descriptive research studies inquire about the nature, frequency, or distribution of variables and or relationships among variables. The study 
area was Akwa Ibom State, Nigeria. The study was conducted at the postgraduate school of the University of Uyo, Uyo, Akwa Ibom state. The choice of this institution was informed by the fact that this institution offers TVET programmes. The target population of the study was 74, consisting of TVET lecturers of the University of Uyo, Uyo, Akwa Ibom state numbering. A total of 48 lecturers representing $65 \%$ of the entire population constituted the sample size for the study. The simple random sampling technique was used in selecting respondents.

A structured questionnaire tagged "Entrepreneurship Training and Integration Questionnaire" (ETIQ) was used for data collection. It was developed through extensive literature review and based on the purpose of the study. There were 30 questionnaire items and respondents were asked to rate the items on a five points Likert scale of degree of agreement and disagreement. The following options thus were: strongly agree (SA) Agreed (A), Undecided (U), Disagreed (DA) and Strongly Disagree (SD). The instrument was face and content validated by three experts, one from Vocational Education, and another from Entrepreneurial studies and the last from Measurement and Evaluation, all from the University of Uyo, Uyo, Akwa Ibom state.

The study adopted the use of descriptive statistics in analysing data collected on research questions one and two. The two research questions were thus answered by the use of mean ratings of the respondents on the methods for integration of entrepreneurship Education in TVET in Nigeria in order to determine the appropriate ones. As a decision rule, the real limits of numbers of the response mode well used to categorise the mean ratings of the respondents. Thus, any mean from 3.5 and above was accepted and agreed, while all means from 3.49 and below were rejected.

Table 1. Decision Rule Schedule

\begin{tabular}{llrl}
\hline Response Mode & Rate & Real limits & Decision \\
\hline Strongly agree & 5 & $4.5-5.0$ & Strongly agree \\
Agree & 4 & $3.5-4.49$ & Agree \\
Undecided & 3 & $2.5-3.49$ & Undecided \\
Disagree & 2 & $1.5-2.49$ & Disagree \\
Strongly Disagree & 1 & $0.5-1.49$ & Strongly Disagree \\
\hline
\end{tabular}

\section{Results and Discussion}

Research Question 1:What are the appropriate methods of integrating entrepreneurship education into TVET in Nigeria?

Table 2: Appropriate Methods of Integrating Entrepreneurship Education Into TVET in Nigeria

\begin{tabular}{|l|l|l|l|}
\hline Items & Methods of Integration & $X$ & Decision \\
\hline 1 & Assignments and Projects & 3.4 & * \\
\hline 2 & Case studies & 3.8 & Agree \\
\hline 3 & Business Games & 3.6 & Agree \\
\hline 4 & Industry Academia Interaction & 3.8 & Agree \\
\hline 5 & Psychological Counselling & 3.5 & Agree \\
\hline 6 & Role Play & 3.0 & $*$ \\
\hline 7 & Structured Syllabus & 3.5 & Agree \\
\hline 8 & Computer based instruction & 3.7 & Agree \\
\hline 9 & Arranging entrepreneurship development programme & 3.4 & * \\
\hline 10 & Arranging more interaction with entrepreneurs & 3.8 & Agree \\
\hline 11 & Creating entrepreneurship development support agencies & 3.0 & * \\
\hline 12 & Give specialisation in entrepreneurial development & 3.0 & * \\
\hline 13 & $\begin{array}{l}\text { Regular visits by Alumnilinteraction with alumni who have } \\
\text { become entrepreneurs }\end{array}$ & 3.5 & Agree \\
\hline 14 & Introduction of Craftsmanship education at the primary level & 3.0 & * \\
\hline 15 & Teacher professional development programme & 3.8 & Agree \\
\hline 16 & On-the-job training for teachers & 3.8 & Agree \\
\hline
\end{tabular}


Table 2 indicated that the respondents agreed that all 10 items were all necessary techniques/methods required for integrating entrepreneurship into TVET. Six of the items could not be considered as appropriate methods of integrating entrepreneurship into TVET in Nigeria based on the decision rule. They had means less than 3.5.

\section{Research Question 2:}

What are the factors of entrepreneurial activities needed by TVET students in Nigeria?

Table 3: Entrepreneurial Activities Needed by TVET Students in Nigeria

\begin{tabular}{|l|l|l|l|}
\hline Items & Activities & $\mathrm{X}$ & \\
\hline 17 & Creativity and innovativeness & 3.8 & A \\
\hline 18 & problem solvion \\
\hline 19 & Risk taking ability & 3.8 & Agree \\
\hline 20 & time management & 3.8 & Agree \\
\hline 21 & high self esteem & 3.5 & Agree \\
\hline 22 & Flexibility & 3.7 & Agree \\
\hline 23 & dignity for labour & 3.0 & * \\
\hline 24 & capacity to change & 3.0 & * \\
\hline 25 & continuous learning & 3.8 & Agree \\
\hline 26 & ability to learn from on-the-job training & 3.5 & Agree \\
\hline 27 & self management & 3.5 & Agree \\
\hline 28 & self confidence & 3.4 & * \\
\hline 29 & strong will power & 3.6 & Agree \\
\hline 30 & team working skills & 3.3 & * \\
\hline
\end{tabular}

Where * Means Disagree

Table 3 indicates that four activities were rejected while 10 were accepted. The activities that were disagreed on include: flexibility (3.0), dignity for labour (3.0), self management (3.4), and strong will power (3.3).

\section{Discussion of findings}

Results of the findings of this study revealed that the most outstanding methods of integrating entrepreneurship into TVET in Nigeria were in the use of appropriate instructional methods like case studies, industry academia interaction, computer based instruction and business games. Others include frequent interaction with entrepreneurs, teacher professional development and on-the-job training. These findings were supported by the report of the National Agency for Enterprise and Construction (2004). The report stated that among other things, entrepreneurship education should detail the extent to which guest lecturers/ practitioners are involved in entrepreneurship programmes. Internship or practical experience is an integral part of the education, and the extent of private business involvement. The report also stressed experimental teaching and culture-affecting activities including the use of role models, a strong focus on instilling an overall entrepreneurial spirit, personal development as well as promoting an experimental approach to entrepreneurship education. This illustrates that entrepreneurship education goes beyond traditional lectures in entrepreneurship. TVET institutions need to apply creative and innovative approaches to teaching as well as promoting practical entrepreneurship skills by combining a theoretical, practical and experimental approach to entrepreneurship education.

Results of the findings of this study further revealed that the entrepreneurial activities and thus qualities to be developed by the students are creative and innovative skills, problem solving skills, risk taking, high self esteem, capacity to change, self confidence and team working skills. This study is supported by a comparative study conducted by Cromie and O'Donoghue (1992) on 194 managers and 661 first year degree undergraduate students with a group of entrepreneurs. They found that managers had high entrepreneurial attitudes by exhibiting characteristics and the nature 
for achievement, internal self control, need for autonomy, creativity, risk taking as well as higher self confidence as compared with the first year undergraduate students. Therefore, these skills were to be developed in the students for them to become successful entrepreneurs. Furthermore, Jacobowitz and Vilder (1982) observed that entrepreneurs commonly share certain personality characteristics. These include: restlessness, independence, take on their own initiatives and extreme self-confidence. Other researchers such as Timmons (1985) and Kirby (2003) have added innovative, action oriented, high need for personal control and highly autonomous to the list of what they see as uniquely entrepreneurial characteristics. Others see entrepreneurship education from a broader perspective. For example, Drucker (1994), Bygrave and Zacharakis (2004), and Timmons and Spinelli (2004) believe that entrepreneurship education should create a capacity for imagination, flexibility, creativity, willingness to think conceptually, and the art to see change as an opportunity. This should be in addition to the basic skills of starting and managing a business.

\section{Conclusion}

The highest pool of potential workforce for any nation is its university students. Integrating entrepreneurship education into TVET programmes will greatly encourage young people to be self reliant especially when encouraged by the government through grants and enabling conditions that promote the ease to set up business. Based on this study, for an individual (youth) to be considered a potential successful entrepreneur, certain prerequisites abound, such as essential characteristics possessed by the individual. These are: creativity and innovativeness, self confidence, problem solving skills, risk taking ability, high self esteem, capacity to change and organisational abilities. The study reveal that a blend of theoretical, practical and experimental approaches to entrepreneurship education, will be most encouraging to TVET students of the nation.

\section{Recommendations}

Based on the findings of the study, the following recommendations were made

1. Creation of entrepreneurship development support agencies by the government.

2. Arranging more interaction between entrepreneurs and TVET students.

3. There should be increased industry academia interaction.

4. Lecturers should use business games, role playing and ICTs for instruction in entrepreneurship education.

5. Students should be guided into discovering knowledge by themselves to spur their creativity and problemsolving skills.

\section{References}

Blanchflower, G., G. \& Andrew J. O. (2007). What Makes a Young Entrepreneur? The tidun

Bygrave, W. D.(2003). A longitudinal study of habitual entrepreneurs: starters and acquirers. (online) Available from: http://taylorandfrancis.metapress.com/(vlhsf321dxq1nm450fgxsw55)/app/hom,[AccessedJune 13 $3^{\text {th }}, 2012$ ].

Cohen, N.(1980). The five ages of the entrepreneur. Venture Magazine.

Cromie, S. \& Donoghue, J.(1992). Assessing entrepreneurial attitudes. International Small Business Journal. 10(2), 66 - 70.

Drucker, P. (1985). Innovation and Entrepreneurship. London: Heinemann.

Federal Republic of Nigeria (2004). National Policy on Education (4th edition,). Lagos: NERDC Press.

Jacobwitz, A. \& Vilder, D. (1982). Characteristics of Entrepreneurs: Implications for vocational guidance. Vocational Guidance Quarterly. 30(3).

Kirby, D.(2003). Entrepreneurship. London: McGraw Hill Publishing.

National Agency for Enterprise and Construction (2004). Entrepreneurship Education at Universities - a Benchmark Study. Background Report for the Entrepreneurship Index. Denmark.

Timmons J. A. (1985). New venture creation: A Guide to Entrepreneurship. Homewood. Irwin.

Timmons J. A. (1994). New venture creation. 4th edition. Homewood. Irwin. 